Aryo Prakoso Wibowo

\title{
PROPORSIONALITAS WARTAWAN TELEVISI LOKAL DI BATU TV
}

\author{
Aryo Prakoso Wibowo \\ Program Studi Ilmu Komunikasi Fisip Universitas Merdeka Malang \\ aryo.prakoso@unmer.ac.id
}

\begin{abstract}
This study aims to determine the extent to which the professionalism of TV journalists to process information to become a debate of opinion for the local community about local phenomena. The process of producing news is important to provide good news content to the public. The good news is presented by journalists who understand and adhere to the journalist's code of ethics. Because journalists are professionals who work based on rules or code of ethics journalism as an operational handle to maintain public confidence, uphold integrity and professionalism. The performance of journalists must uphold the code of ethics of television journalists, among other things "not to engineer events, images or sounds to be made news" (article 5 point c) and then in chapter 10 point c reads "as distinguish between the facts and opinions, . It relies heavily on the quality of human resources of television journalists to produce quality news. The results obtained in the study show that Journalists at Batu TV are not "free" individuals who produce truth through journalistic outcomes, but rather because of the demands of corporate capitalism. Batu $T V$ prioritizes Profit Oriented so that the news is dominated by order news (blockingtime). Under these circumstances, journalists are faced with a dilemma between a pure report in the journalist's code of ethics with news of orders being polished for commercial demands.
\end{abstract}

Keywords: Code of Ethics Journalism, News, Local Journalists

\begin{abstract}
Abstrak
Penelitian ini bertujuan mengetahui sejauh mana profesionalisme jurnalis tv mengolah informasi sehingga menjadi perdebatan pendapat bagi masyarakat lokal mengenai fenomena lokal. Proses produksi berita merupakan hal yang penting untuk memberikan isi berita yang baik kepada masyarakat. Berita yang baik disajikan oleh wartawan yang paham dan taat pada kode etik jurnalis. Sebab wartawan adalah seorang profesional yang bekerja berdasarkan kaidah atau kode etik jurnalistik sebagai pegangan operasional untuk menjaga kepercayaan publik, menegakkan integritas dan profesionalisme. Kinerja para jurnalis harus menjunjung kode etik jurnalis televisi, antara lain "tidak merekayasa peristiwa, gambar maupun suara untuk dijadikan berita"(pasal 5 poin c) kemudian pada pasal 10 poin c berbunyi "sebisanya membedakan antara kejadian (fact) dan pendapat (opinion). Hal ini sangat bergantung pada kualitas sumber daya manusia jurnalis televisi untuk menghasilkan berita yang berkualitas. Hasil yang diperoleh dalam penelitian menunjukkan bahwa Jurnalis di Batu TV tidak menjadi pribadi "bebas" yang memproduksi kebenaran melalui hasil jurnalistik, namun lebih karena tuntutan kapitalisme korporasi. Batu TV mengutamakan Profit Oriented sehingga pemberitaan didominasi oleh berita pesanan (blockingtime). Pada kondisi ini, para jurnalis dihadapkan pada dilema antara sebuah pemberitaan murni sesuai kode etik jurnalis dengan berita pesanan yang dipoles demi tuntutan komersil.
\end{abstract}

Kata Kunci : Kode Etik Jurnalistik, Berita, Jurnalis Lokal 


\section{PENDAHULUAN}

Media massa saat ini memiliki peran yang sangat penting untuk memenuhi kebutuhan akan informasi kepada masyarakat. Dari sekian banyak media massa yang muncul dan bersaing untuk memproduksi sebuah informasi, televisi nampaknya masih menjadi media unggulan dengan kelebihan audio visualnya. Stasiun televisi sangat bersemangat dalam berlomba merebut perhatian pemirsa atau penonton. Hal ini dapat dilihat dengan banyaknya program - program yang diproduksi guna memenuhi sebuah informasi yang dibutuhan audience, terutama program pemberitaan.

Tidak dapat dihitung berapa puluh berita dalam sehari penonton disuguhi oleh beberapa stasiun televisi. Hal yang menarik dan perlu ditelaah adalah sejauh mana informasi tersebut diproduksi dan dapat didistribusikan secara cepat oleh media massa kepada masyarakat. Persaingan televisi nasional setelah era reformasi sangatlah berkembang pesat. Mulai dari jumlah media massa yang bermunculan hingga aneka ragam bentuknya. Baik kemunculan perusahaan berskala nasional maupun lokal juga ikut meramaikan dunia media massa. Kemunculan televisi lokal menambah ragam pilihan bagi masyarakat untuk mendapatkan kebutuhan konten program informasi, media hiburan serta nilai pemberitaan yang baru. Dengan kata lain, televisi lokal harus memberikan nilai baru bagi masyarakat lokal mengenai isu-isu atau persoalan-persoalan lokal yang sedang dihadapi. Selain itu televisi lokal juga wajib membuat sebuah program untuk menjadi sarana pengembangan potensi daerah. Hal ini tidak terlepas dari peran televisi lokal yang juga mulai membuat berita sendiri. Walaupun jangkauan siaran media televisi lokal masih terbatas, yaitu hanya dapat dinikmati oleh masyarakat di wilayah tersebut.

Selain keterbatasan jangkauan siaran, televisi lokal juga cenderung tidak memperhatikan tuntutan profesionalisme wartawan, tidak memakai standar kompetensi yang jelas dalam merekrut para karyawannya. Sehingga mereka yang terkadang tidak memiliki pengalamanpun direkrut sebagai karyawan atau bahkan pendidikan yang dimilikinya tidak berhubungan sama sekali dengan pertelevisian. Langkah tersebut menyebabkan rendahnya kualitas sumber daya manusia dalam pertelevisian lokal. Keterbatasan Sumber Daya Manusia (SDM) dalam pertelevisian lokal memiliki korelasi positif dengan terhambatnya perkembangan pertelevisian lokal. Demikian halnya dengan Batu Televisi (Batu TV), yaitu media televisi lokal di Kota Batu Jawa Timur. Masalah sumber daya manusia dalam hal penyiaran menyebabkan kekurangan - kekurangan berkaitan dengan kualitas berita (peliputan dan penyuntingan). Salah satu penyebab adalah keterbatasan biaya sebab cakupannya lokal sehingga iklan yang masuk juga sifatnya lokal sehingga dalam hal tertentu kurang bisa bersaing.

Jurnalis atau wartawan adalah sebuah profesi. Karena itu, seorang jurnalis atau wartawan terikat oleh kaidah-kaidah profesionalisme yang sesuai dengan bidangnya. Dengan kata lain wartawan adalah pekerja profesional yang sudah seharusnya mematuhi kode etik jurnalistik. Untuk menjamin kemerdekaan pers dan memenuhi hak publik dalam memperoleh informasi yang benar, jurnalis Indonesia memerlukan landasan moral dan etika profesi sebagai pedoman operasional untuk menjaga kepercayaan publik, menegakkan integritas dan profesionalisme. Atas dasar 
itu, wartawan Indonesia menetapkan dan mentaati kode etik jurnalistik demi memelihara dan menjaga standar kualitas pekerjaan si jurnalis bersangkutan, tetapi juga untuk melindungi atau menghindarkan khalayak masyarakat dari kemungkinkan dampak yang merugikan dari tindakan atau perilaku keliru dari si jurnalis.

Jacoeb Oetama (1995) untuk lebih mengarahkan para wartawan dalam melaksanakan tugas, khususnya kepada wartawan pemula, biasanya dibekali dengan teknik pencarian, pengumpulan, penulisan, dan pelaporan berita dengan $5 \mathrm{~W}+1 \mathrm{H}$. Sebuah berita dianggap memenuhi kelengkapan jika secara elementer memenuhi kriteria ini. Wahidin (1999), melihat pada kemasan yang selama ini dijadikan pedoman di dalam pencarian, dan penulisan khalayak, mula - mula dikenal jenis reportase yang secara umum dikembangkan para jurnalis, termasuk liputan dalam bidang politik. Jenis reportase dimaksud adalah : reportase faktual; reportase interpretatif; reportase jurnalisme baru.

Pada reportase faktual, seorang wartawan menyajikan fakta berdasar apa adanya. Semacam laporan pandangan mata yang mempersilahkan pada pemirsa, pembaca, atau pendengar untuk memberikan penilaian sendiri terhadap materi yang disajikan. Sementara untuk reportase interpretatif telah diberikan pemaknaan tertentu dengan memasukkan unsur opini pada sajian yang dikemas dalam bentuk berita. Ada unsur pemaksaan kendatipun dalam intensitas kecil kepada khalayak untuk mempersepsikan suatu sajian sesuai dengan arah yang diinginkan wartawan.

Bentuk ketiga dikualifikasikan sebagai bentuk jurnalisme baru atau new journalisme hakikatnya bukanlah reportase tetapi sebuah teknik penyajian. Atau tepatnya teknik penulisan satu fakta yang dikemas sedemikian rupa sehingga didalamnya ada unsur opini dengan arah tertentu yang lebih halus dan terencana. Misalnya dengan memasukkan data-data sejenis dari kejadian terdahulu sehingga (sepertinya) yang disampaikan itu benar.

Berdasarkan kaidah - kaidah profesionalisme wartawan, maka dalam memberitakan suatu perisitiwa atau kejadian, pers dituntut untuk memberitakan secara berimbang. Artinya dalam suatu pemberitaan bila terdapat dua pihak yang saling bertentangan, pers sebagai media komunikasi massa harus memberitakannya secara berimbang dari kedua belah pihak sehingga pihak yang berperkara dapat saling mengungkapkan alasan-alasan atau argumen-argumennya sehingga dirasakan adil. Keseimbangan berita bukan berarti kedua belah pihak diberikan jumlah kolom atau kata yang sama tetapi yang dimaksud berimbang adalah kedua belah pihak diberitakan dalam satu kesatuan berita.

Abrar (2005 : 23-29) mengatakan teknik pencarian berita sendiri memiliki arti sebagai sebuah peristiwa atau fenomena sosial yang telah dikonstruksi oleh jurnalis. Sehingga sebelum membahas lebih jauh tentang jurnalis profesional, sangatlah penting untuk mendeskripsikan teknik mengumpulkan fakta, yang terdiri dari empat cara, yaitu :

a. Observasi

Secara sederhana observasi merupakan pengamatan terhadap realitas sosial. Ada pengamatan langsung dan pengamatan tak langsung.

b. Wawancara

Wawancara adalah tanya jawab antara seorang wartawan dengan narasumber untuk mendapatkan data tentang sebuah 
fenomena (Anderson, 1987:184). Dalam hal ini yang perlu diperhatikan adalah :

1. Posisi narasumber dalam wawancara, sebelum melakukan wawancara wartawan harus menanyakan keinginan narasumber.

2. Posisi wartawan dalam wawancara Kedudukan wartawan adalah penjaga kepentingan umum. Para wartawan berhak mengorek informasi yang berkaitan dengan kepentingan umum dari narasumber. Menurut para ahli, ada tujuh jenis wawancara, yaitu man in the street interview, casual, personal, news peg, telephone, question dan group interview (Anderson, 1987:207-213).

3. Konferensi Pers

Pernyataan yang disampaikan seseorang yang mewakili sebuah lembaga mengenai kegiatannya kepada para wartawan. Biasanya menyangkut citra lembaga, peristiwa yang sangat penting dan bersifat insidental. Pada setiap konferensi pers, setiap wartawan memiliki hak yang sama untuk mengajukan pertanyaan kepada orang yang memberikan konferensi pers.

4. Press Release

Bisa diartikan sebagai siaran pers yang dikeluarkan oleh suatu lembaga, organisasi atau seorang individu kepada wartawan. tidak ada keharusan bagi wartawan untuk memuat siaran pers ini. Dan juga tidak ada kesempatan wartawan untuk bertanya kepada pihak yang mengeluarkan siaran pers.

Ruang redaksi sebagai "jantung" dari segala aktivitas jurnalisme tentu memiliki kebijakan untuk mengatasi dan mengantisipasi segala keterbatasan Batu TV dalam hal pemberitaan, terutama tarik menarik berbagai kepentingan yang dapat mempengaruhi kinerja jurnalistiknya. Meskipun sebuah karya jurnalistik merupakan karya tim peliputan yang terdiri dari reporter dan kameraman, namun hasil akhir hingga berita disiarkan harus melalui proses pengolahan yang merupakan kerja bersama keredaksian. Baik reporter, redaktur dan Batu TV secara organisasi tentu memberi pengaruh dalam membentuk setiap berita yang akhirnya disiarkan kepada masyarakat.

Wartawan yang profesional seharusnya mentaati dan menjalankan etika jurnalistik. Kepatuhan etis wartawan Indonesia itu terangkum dalam Kode Etik Wartawan Indonesia (KEWI) yang sudah ditetapkan Dewan Pers sebagai Kode Etik Jurnalistik bagi para wartawan di Indonesia. Kepatuhan pada kode etik merupakan salah satu ciri profesionalisme, di samping keahlian, keterikatan, dan kebebasan. Dengan berpedoman pada kode etik itu, seorang wartawan tidak akan mencampuradukkan antara realita dan opini dalam menulis berita; tidak akan membuat berita fitnah, sadis, dan cabul; tidak akan "menggadaikan profesionalisnya" dengan menerima amplop; hanya menginformasikan yang benar atau faktual; dan sebagainya.

Profesionalisme wartawan meliputi: (1) teknik, yaitu keterampilan memformat realitas sosial empirik yang memenuhi newsworthy dan bermanfaat untuk masyarakat informasi; (2) etika, yaitu standar tindakan yang dipandang baik untuk membimbing ketrampilan wartawan. Pada titik ini, etika menjadi bagian yang tidak terpisahkan dari profesionalisme. Bahkan keberadaan profesionalisme wartawan bertolak dari etika wartawan ini (Siregar \& Suarjana, 1991: 2-3). 
Sehubungan dengan penyajian berita harus diingat bahwa posisi wartawan bukan semata-mata sebagai pencari fakta, tetapi wartawan harus sadar terhadap tanggung jawabnya untuk menenteramkan masyarakat. Sajian berita tidak hanya harus berangkat dari asumsi yang tidak umum, akan tetapi harus dikembangkan sedemikian rupa agar supaya informasi tersebut tidak terlihat umum. Dan supaya mempunyai nilai tersendiri sehingga dapat sebagai bahan sajian fakta.

Oleh karena itu, Pengurus Persatuan Wartawan Indonesia (PWI) Pusat merasa perlu menyelenggarakan kegiatan pelatihan buat sejumlah wartawan untuk menjadi asesor, tim penilai Standar Kompetensi Wartawan (SKW) di Bogor, 17 - 18 Juni 2011. PWI Pusat memandang perlu, setiap wartawan Indonesia harus memiliki standar kompetensi sebagai perwujudan dari aktifitas wartawan sebagai sebuah profesi, sebagaimana profesi lain, apakah itu dokter, notaris, pengacara, atau profesi lainnya.

Kovach dan Rosenstiel (2001:45), merumuskan prinsip-prinsip itu dalam 9 (Sembilan) Elemen Jurnalisme, yaitu :

1. Kewajiban utama jurnalisme adalah pada pencarian kebenaran.

2. Loyalitas utama jurnalisme adalah pada warga Negara.

3. Esensi jurnalisme adalah disiplin verifikasi.

4. Jurnalis harus menjaga independensi dari obyek liputannya.

5. Jurnalis harus membuat dirinya sebagai pemantau independen dari kekuasaan.

6. Jurnalis harus memberi forum bagi publik untuk saling-kritik dan menemukan kompromi.

7. Jurnalis harus berusaha membuat hal penting menjadi menarik dan relevan.
8. Jurnalis harus membuat berita yang komprehensif dan proporsional.

9. Jurnalis harus diperbolehkan mendengarkan hati nurani personalnya.

Wartawan bekerja dalam suatu aturan tertentu yang sering disebut dengan Kode Etik Jurnalistik. Tujuannya agar ada penghargaan terhadap hak setiap manusia dan wartawan bekerja dalam suatu aturan yang baku.Tetapi sebelum membahas tentang kode etik jurnalistik, kita akan melihat beberapa kendala dalam penulisan berita terlebih dahulu. Menurut Kusumaningrat (2005: 16), disebutkan mempunyai beberapa rambu-rambu dan etika bagi wartawan dalam penulisan berita. Memang kendala dalam menghimpun berita sering kali datang dari ketentuan-ketentuan yang tercantum dalam Kode Etik Jurnalistik yang merupakan undang-undangnya profesi wartawan. Kode Etik Jurnalistik mengalami beberapa kali perubahan dan penyempurnaan.

Media massa menjadi penyeimbang yang tidak dapat dianggap remeh dari kekuasaan-kekuasaan lain di tataran tingkat eksekutif, legislatif, dan yudikatif. Menjadi seorang wartawan merupakan tugas sebagai jurnalis yang sangat penting dalam sebuah negara. Namun wartawan sering kali menemukan benturan atau permasalahan dalam prakteknya. Sering ditemui wartawan yang menyalahgunakan statusnya sebagai jurnalis untuk kepentingan - kepentingan yang menguntungkan pribadi atau sering melakukan kegiatan yang menimbulkan kerugian pada orang lain. Berangkat dari sinilah, maka lahir apa yang disebut Kode Etik Jurnalistik.

Sementara pada tingkatan rutinitas media, ada tiga sumber utama yang menjadi acuan bisa dibilang paksaan bagi media dalam menyusun isi berita. Yang pertama, 
orientasi pada audiens media misalnya dalam nilai berita yang disusun berdasarkan peristiwa yang paling menarik. Kedua, organisasi media sebagai pemroses informasi (prosesor). Dalam redaksi telah terbangun sistem kerja yang menjadi standard dan dipahami oleh semua anggota misalnya sistem tenggat waktu (deadline) dan sistem pengkategorian berita. Ketiga, sumber informasi eksternal yang biasanya memberikan informasi kepada media baik dalam bentuk wawancara, laporan perusahaan dan data-data lain. Media cukup bergantung pada narasumber-narasumber semacam ini terutama untuk peristiwaperistiwa penting (shoemaker \& Rese, 1996:105-123).

Tingkatan ketiga adalah pengaruh yang diberikan oleh organisasi media misalnya struktur organisasi media bahkan hingga tingkat kepemilikan media. Kepemilikan pun akan berimbas pada orientasi media dimana sebagai media ingin menghasilkan keuntungan namun sebagian lainnya ingin menghasilkan karya berkualitas, mendapatkan pengakuan secara professional atau melayani kebutuhan publik.

Tingkatan keempat adalah faktorfaktor di luar media yang mempengaruhi konten media massa. Faktor-faktor tersebut antara lain sumber informasi atau narasumber media seperti misalnya kelompok-kelompok kepentingan khusus dan kampanye humas. Selain itu, sumber pemasukan financial media massa juga member pengaruh seperti pengiklan, audiens, institusi bisnis, pemerintah, lingkungan ekonomi dan teknologi (Shoemaker \& Reese, 1996: 172).

Tingkatan kelima adalah level ideologi. Pada level ini akan timbul pertanyaan kepentingan siapa yang terkait dengan rutinitas dan kerja media massa, kekuasaan dalam masyarakat dan bagaimana kekuasaan tersebut berperan dalam media massa (Shoemaker \& Reese, 1996:215).

\section{Metode Penelitian}

Penelitian ini merupakan penelitian kualitatif dengan perspektif studi kasus. Moleong (2005) studi kasus berusaha untuk mengungkap dan mempelajari serta memahami suatu kejadian beserta konteksnya yang khas dan unik yang dialami oleh individu hingga mempengaruhi keyakinan individu tersebut. Dengan demikian dalam mempelajari serta memahami sebuah kejadian, haruslah berdasarkan sudut pandang, paradigma dan keyakinan langsung dari individu tersebut sebagai subjek yang mengalami secara langsung. Dalam penelitian ini, penulis melakukan analisa deskriptif terhadap profesionalisme jurnalis televisi lokal, yang dalam hal ini Batu TV sebagai obyek penelitian, dimana masalah profesionalisme jurnalis TV lokal ini merupakan sebuah fenomena dan realitas sosial yang terjadi yang dapat berimbal balik pada kemajuan dan perkembangan TV lokal tersebut.

Sesuai dengan topik dan fokus penelitian ini, maka informannya terdiri atas 2 orang wartawan Batu Televisi dan pemilik Batu Televisi. Untuk memperoleh data yang diperlukan, peneliti menggunakan teknik pengumpulan data sebagai berikut :

1). Wawancara yang dilakukan oleh peneliti dimaksudkan untuk mengetahui lebih jelas tentang berbagai hal secara langsung dari sumber-sumber yang berkepentingan dan berkompeten serta untuk merekonstruksi mengenai orang, kegiatan, kejadian, organisasi, perasaan, motivasi, tuntutan, kepedulian dan lainlain. Jenis wawancara yang akan 
dilakukan dalam penelitian ini adalah wawancara tak terstruktur. Dalam wawancara ini informan biasanya terdiri dari mereka yang terpilih saja karena sifatnya yang khas. Biasanya mereka memiliki pengetahuan dan mendalami situasi, dan mereka lebih mengetahui informasi yang diperlukan. Dalam penelitian ini wawancara dilakukan dengan para wartawan.

2). Observasi. Yakni peneliti terjun langsung pada objek penelitian agar dapat memperoleh data yang dapat dipertanggungjawabkan, dalam hal ini peneliti mengadakan pengamatan atau pencatatan secara sistematis terhadap gejala, peristiwa ataupun perilaku obyek yang diteliti pada perusahaan. Observasi ini bertujuan untuk mengetahui keadaan yang sebenarnya dan data dikumpulkan untuk dicocokkan dengan hasil wawancara.

3.) Dokumentasi. Teknik ini digunakan untuk mengumpulkan data-data arsiparsip tertulis berupa profil perusahaan, kepemilikan dan badan hukum, struktur organisasi. Teknik ini untuk mengumpulkan data sekunder yang mendukung perolehan data wawancara.

Penelitian ini tidak membahas semua dimensi dalam Profesionalisme Wartawan Televisi, melainkan hanya dibatasi pada beberapa dimensi: pertama, difokuskan pada Keterampilan Teknis, meliputi : pencarian fakta, analisis media, menulis pendapat, komentar. Kedua, membahas tentang Kepatuhan Etis, meliputi : melindungi sumber berita, menghormati hak sumber berita, berpedoman pada perilaku etis, menjaga kebenaran berita, menghargai harkat dan martabat sumber berita. Ketiga, data hasil penelitian ini dikaji dengan menggunakan konsep Kode Etik Jurnalistik.

\section{Hasil Penelitian dan Pembahasan}

Penelitian ini mengkaji mengenai praktik jurnalistik yang dilakukan oleh para wartawan Batu TV dalam mengumpulkan berita, menulis berita dan menyiarkan berita tersebut. Penekanan pada kompetensi wartawan dilandasi oleh kesadaran bahwa wartawan merupakan ujung tombak pembuat berita atau peliput fakta yang harus mempunyai misi yang baik dan dapat dipertanggungjawabkan. Wartawan terlibat langsung dalam pembuatan/produksi berita. Karena itu, wartawan harus dapat merefleksi semua realitas sosial yang benar, serta menyuarakan segala kepentingan yang ada dari sebuah sistem sosial secara professional.

Profesionalisme wartawan meliputi: (1) teknik, yaitu keterampilan memformat realitas sosial empirik yang memenuhi newsworthy dan bermanfaat untuk masyarakat informasi; (2) etika, yaitu standar tindakan yang dipandang baik untuk membimbing ketrampilan wartawan. Pada titik ini, etika menjadi bagian yang tidak terpisahkan dari profesionalisme.

Sebelum berita televisi ditayangkan, harus melalui proses panjang dengan melibatkan berbagai aktor/pelaku dibalik pembuatannya, seperti yang diungkapkan oleh redaksi berita Batu TV berikut ini : Sebelum mengkaji atau menggali seluk beluk proses pembuatan atau produksi sebuah berita televisi di Batu TV ini, penting untuk mengetahui bahwa dibalik berita yang ditayangkan ada sejumlah orang yang sangat berperan sekaligus bertanggung jawab terhadap tayangan tersebut. Istilahnya, bagaimana mengangkat dan membuat sebuah berita yang berkualitas baik dari isi, kemasan maupun dampak/efek yang 
ditimbulkannya atau bagaimana kira - kira respon khalayak terhadap berita tersebut. Yang saya maksudkan orang - orang penting dalam proses produksi berita adalah wartawan televisi/kameramen, Editor, Penulis Narasi, Dubber/Pengisi Suara. Hasil kerja merekalah yang kemudian dibacakan oleh presenter. Dari penjelasan tersebut, diketahui bahwa para pelaku dalam proses produksi sebuah berita televisi di Batu TV adalah: 1) Wartawan televisi/kameramen, 2) Editor (berita dan gambar), 3) Penulis Narasi, 4) Dubber/Pengisi Suara.

Dalam proses produksi/pembuatan berita, ada beberapa hal yang harus diperhatikan agar berita tersebut bermakna dan pesan yang disampaikan dapat diterima oleh pemirsa/penonton. Faktor - faktor yang secara khusus dilihat atau dicermati dalam penelitian ini adalah :

1. Faktor Individu:

Individu yang dimaksud disini adalah wartawan yang merupakan garda paling depan dalam penentuan isi berita. Wartawan merupakan orang yang terkait langsung (menyaksikan) sebuah realitas/peristiwa yang akan dilaporkannya. Dalam hal ini kapasitas seorang wartawan (pendidikan, pengalaman, suku, agama, jender, dan sikap individu) dalam mencari dan menemukan berita akan berpengaruh terhadap peristiwa yang akan dilaporkannya. Wartawan di Batu TV berjumlah empat (4) orang. Dengan jumlah yang minim dan materi kerja yang banyak serta ketidakjelasan standar operasional prodesur, membuat beberapa wartawan mengerjakan satu pekerjaan untk semua jenis pemberitaan. Berikut adalah petikan wawancara bersama salah satu jurnalis di Batu TV. Hasil wawancara ini merupakan salah satu informasi penting untuk mengetahui dan mengukur kinerja jurnalisme di Batu TV. Peneliti berhasil mewawancarai dua dari empat wartawan Batu TV. Wartawan Batu TV dalam menentukan sebuah berita harus mengetahui apa yang penting untuk diketahui oleh masyarakat, khususnya wilayah Malang Raya. Yang pertama dilakukan adalah melakukan penentuan fokus berita apa yang akan diambil oleh seorang wartawan untuk keesokan harinya. Maka mereka baru dapat menentukan jenis berita. Wartawan tersebut dapat melihat jadwal seperti di kantor pemkab, kantor polisi, dan sebagainya. Mereka akan melihat agenda apa saja yang akan terjadi untuk dapat dimasukkan dalam sebuah pemberitaan. Sehingga mereka menyebut dengan berita peristiwa teragenda. Ada juga wartawan yang mengambil berita dengan cara pesanan. Berita tersebut merupakan kegiatan dari sebuah kelompok yang ingin kegiatan tersebut diliput oleh media. Biasanya berita ini disebut dengan blocking time. Blocking time sendiri diartikan sebagai pembelian jam tayang di televisi lokal tersebut. Dan hal ini sangat dipengaruhi oleh faktor ekonomi politik media. Dari penjelasan sekilas, maka dapat disimpulkan bahwa media televisi sangat berpengaruh terhadap perkembangan masyarakat. Di Batu TV, para wartawan melakukan pengambilan berita sendiri tanpa bantuan seorang reporter. Dan membuat narasi sendiri yang kemudian dilakukan pengisian suara(dubbing) sendiri oleh wartawan tersebut. Lain halnya jika di Stasiun TV lainnya, seorang wartawan dibantu oleh seorang reporter yang berguna untuk 
mencari data yang kemudian dibuat untuk narasi yang nantinya dibaca oleh seorang dubber yang bekerja juga sebagai pembawa berita atau presenter. Sehingga setiap substansi dapat bekerja sesuai dengan aturan dan maksimal.

2. Rutinitas Media Dalam Mengkonstruksi Realitas Sosial

Setiap organisasi, termasuk Batu TV memiliki rutinitas yang biasa dilakukan dalam mengolah peristiwa/cerita/realitas dari berbagai sumber berita, termasuk salah satunya dari reporter. Batu TV sebagai media televisi tentu berbeda dengan stasiun televisis lainnya dalam menentukan suatu berita. Apakah sebuah berita layak dipublikasikan atau tidak, biasanya ditentukan oleh rutinitas sehari-hari yang menjadi prosedur standard. Untuk itu, peran wartawan sebagai bagian terdepan dalam mencari dan menemukan berita, kemudian mengangkat dan mengemas peristiwa atau cerita menjadi berita yang menarik dan bernilai bagi masyarakat sangat menentukan. Pekerjaan seperti itu sudah menjadi rutinitas dengan kerangka cara kerja yang sudah ada. Untuk bisa mengerjakan berita yang baik dan menarik, wartawan harus mempunyai ilmu di bidang tekhnik jurnalistik. Sebab, tugas dan tanggung jawabnya sangat penting, dimana wartawan tersebut setelah melakukan pengambilan gambar atau take gambar, mereka membuat narasi yang digunakan untuk menceritakan suatu peristiwa atau berita. Dan narasi tersebut menceritakan apa saja yang terjadi didalam berita. Karena selain gambar yang diperlihatkan kepada pemirsa, narasi juga dibacakan oleh wartawan tersebut, sehingga gambar tersebut tidak berjalan monoton. Apabila wartawan telah melakukan kedua kegiatan tersebut, mereka menyerahkan berita dan narasi serta dubbing tersebut kepada bagian redaksi. Tidak lupa juga seorang wartawan harus dapat membuat sebuah kepala berita atau lead berita yang dimana hal ini berguna untuk memberikan topik berita.

3. Faktor Organisasi Media

Disini dimaksudkan bahwa Batu TV sebagai sebuah organisasi memiliki struktur. Hal ini menggambarkan polapola reguler perilaku yang saling bertautan antara satu bagian dengan bagian lainnya. Sebagai organisasi media massa, Batu TV memiliki visi, misi dan tujuan yang seringkali memberi pengaruh pada isi berita. Karena itu, seringkali idealisme wartawan/reporter/kameramen harus diselaraskan dengan idealisme dan tuntutan organisasi.

Footlick (dalam Shoemaker \& Reese, 1996: 72) mengatakan bahwa jurnalis yang baik sedikit tau tentang banyak hal, artinya jurnalis dituntut untuk menguasai banyak pokok bahasan mulai dari kebijakan asing, politik, sejarah, ekonomi dan lain-lain. Ini merupakan kualitas fundamental yang diberikan institusi pendidikan tinggi khususnya komunikasi massa. Shoemaker melalui penelitiannya menemukan bahwa pendidikan dasar komunikasi massa dirancang untuk mempersiapkan jurnalis menjadi insiders dan oursiders yang kritis terhadap berbagai institusi social termasuk juga media massa. Pada akhirnya pendidikan menentukan bagaimana cara seorang reporter memandang dunia dan menggali kedalamannya.

Sementara itu karakteristik kepercayaan yang dianut reporter setidaknya 
menunjukkan bias dalam penulisan berita. Shoemaker \& Reese (1996: 254) mengatakan bahwa orang-orang yang memiliki kesamaan dengan jurnalis akan ditampilkan secara berbeda dengan orangorang yang tidak memiliki kesamaan. Hal ini merujuk pada karakteristik demografis reporter seperti misalnya jenis kelamin, etnis, orientasi seksual dan lain-lain. Reporter perempuan akan menghasilkan tulisan yang berbeda mengenai issue perempuan bila dibandingkan dengan reporter pria, begitupun dengan karakteristik lain yang mempengaruhi bagaimana sebuah issue dibingkai.

Jurnalis Batu TV dalam hal ini kurang menunjukkan pengetahuan dan kompetensinya sebagai jurnalis sehingga belum dapat menghasilkan konten berita yang berkualitas dan mendalam. Hal ini berkaitan erat dengan tingkat pendidikan jurnalis itu sendiri. Disatu sisi, permasalahan tingkat pendidikan memang tidak menjadi masalah mengingat masih belum adanya peraturan resmi yang mengharuskan jurnalis berpendidikan minimal strata $1 . \quad$ Pada peraturan dewan pers No.1/PeraturanDP/II/2010 tentang Standart Kompetensi Wartawan, dituliskan bahwa kompetensi wartawan pertama tama berkaitan dengan kemampuan intelektual dan pengetahuan umum. Kompetensi wartawan yang dimaksud adalah kemampuan memahami etika dan hukum pers, konsepsi berita, penyusunan dan penyuntingan berita serta bahasa. Hal yang terakhir menyangkut keterampilan melakukannya, seperti juga keterampilan yang bersifat teknis sebagai wartawan professional, yaitu mencari, memperoleh, menyimpan, memiliki, mengolah serta membuat dan menyiarkan berita. Berdasarkan hal tersebut maka para jurnalis atau wartawan diwajibkan mengikuti ujian kompetensi yang dilakukan oleh lembaga yang telah diverifikasi Dewan Pers, yaitu perusahaan pers, organisasi wartawan, perguruan tinggi atau lembaga pendidikan jurnalistik. Shoemaker \& Reese (1996: 225) mengatakan bahwa semakin lama seorang jurnalis bekerja pada suatu institusi media mereka akan semakin terbiasa dengan kebijakan organisasi baik tertulis maupun tidak tertulis. Meskipun secara sadar jurnalis Batu TV memahami bahwa regulasi dalam penyiaran menjadi pedoman utama dalam menyusun isi siaran berita, akan tetapi tidak mudah dijalankan atau diterapkan secara profesional.

Bahwa dikatakan dalam memproduksi berita harus mempunyai standar operasional prosedur (SOP) yang digunakan sebagai dasar pembuatan berita. Dasar utama yang harus dikuasai wartawan adalah dengan adanya isi berita $5 \mathrm{~W}+1 \mathrm{H}$. Selain itu seorang wartawan di Batu TV juga harus memiliki dasar, memahami teknis cara mencari berita, menulis berita, bahkan sampai teknik wawancara. Standar teknis tersebut merupakan standar dasar yang harus dimiliki oleh setiap jurnalis. Standar Operasional Prosedur merupakan standar dasar profesionalitas jurnalis. Sehingga tidak ada alasan sebuah media tidak memiliki SOP yang baku. Konsep jurnalis yang profesional yaitu jurnalis yang memahami tugasnya dan yang memiliki ketrampilan jurnalistik. Keterampilan dasar tersebut antara lain: melakukan reportase, wawancara, dan menulis berita yang akurat dan bagus. Tentu saja dengan bahasa Indonesia yang baik dan benar. Para jurnalis yang bertugas wajib menguasai beberapa standar teknis kinerja yang menjadi dasar kegiatan jurnalistiknya. Biasanya mengacu kepada SOP setiap lembaga pers termasuk Batu TV, yaitu: 
Aryo Prakoso Wibowo

1. Menguasai keterampilan jurnalistik. Seorang wartawan haruslah memiliki keahlian (expertise) menulis berita sesuai kaidah jurnalistik. Wartawan tersebut harus menguasai teknik menulis berita, juga feature dan artikel. Untuk itu, wartawan setidaknya pernah mengikuti pelatihan dasar jurnalistik sehingga terlatih dengan baik. Keterampilan jurnalistik meliputi teknik pencarian berita dan bagaimana cara menulis berita, selain pemahaman yang baik tentang makna sebuah berita wartawan haruslah memahami berita, nilai, macam-macam berita, produksinya hingga kaidah umum penulisan.

2. Menguasai bidang liputan (beat). Wartawan idealnya memahami dan menguasai segala hal, sehingga mampu menulis dengan baik dan cermat. Namun, yang terpenting seorang wartawan harus menguasai bidang liputan dengan baik. Wartawan harus menguasai istilah - istilah di bidang yang digelutinya. Jika tidak menguasai ada penundaan liputan dan memilih bidangyang sesuaikarena ketidak tepatan tersebut akan berakibat salah tulis, salah tangkap, ataupun tidak cermat dalam menulis berita.

3. Memahami serta mematuhi etika jurnalistik. Wartawan yang profesional memegang teguh etika jurnalistik. Untuk wartawan Indonesia, etika itu terangkum dalam Kode Etik Wartawan Indonesia (KEWI) yang sudah ditetapkan Dewan Pers sebagai Kode Etik Jurnalistik bagi para wartawan di Indonesia. Kepatuhan pada kode etik merupakan salah satu ciri profesionalisme, di samping keahlian, keterikatan, dan kebebasan. Dengan pedoman kode etik itu, seorang wartawan tidak akan mencampuradukkan antara fakta dan opini dalam menulis berita; tidak akan menulis berita fitnah, sadis, dan cabul; tidak akan "menggadaikan kebebasannya" dengan menerima amplop; hanya menginformasikan yang benar atau faktual; dan sebagainya.

Berbicara mengenai kode etik berarti berkaitan dengan kepatuhan dalam memproduksi berita. Berita yang terkumpul dikemas sesuai standar pemberitaan yang layak serta mengedepankan etika profesinalisme dalam mengabarkannya. Halhal yang berkaitan dengan kepatuhan etis antara lain: melindungi sumber berita, menghormati hak sumber berita, berpedoman pada perilaku etis, menjaga kebenaran berita, dan menghargai harkat dan martabat sumber berita. Standar etika inilah yang harus dimiliki oleh para jurnalis Batu TV. Sebab inilah standar profesionalisme jurnalistik yang sesungguhnya. Kepatuhan etis menjadi sebuah acuan dalam memproduksi berita. Seringkali terjadi kekerasan kepada para jurnalis karena terjadi kesalahpahaman dalam penerapan standar etis ketika mencari fakta dan menulis berita. Hal yang paling sering terjadi yaitu ada teguran atau keluhan dari sumber berita mengenai pemberitaan yang berlebihan atau yang tidak berdasarkan fakta ketika wawancara. Atau jenis berita yang sumbernya off the record tetapi ternyata dalam praktiknya tetap mencantumkan nama narasumber. Yang tersebutkan di atas adalah contoh beberapa standar etis yang seringkali terlanggar oleh para jurnalis. Hal ini sudah ditegaskan pada pasal 3 Kode Etik Jurnalis Televisi bahwa Wartawan Indonesia selalu menguji informasi, memberitakan secara berimbang, tidak mencampurkan fakta dan opini yang menghakimi. 
Lebih jauh, sesuai dengan hasil wawancara mengenai profesionalitas yang diterapkan di Batu TV, terdapat beberapa hal penting yang dikemudian hari akan mengabaikan profesionalisme. Kita tahu, para jurnalis adalah "pegawai bayaran", dan yang membayar adalah perusahaan pers. Ada kekhawatiran, bahwa profesi semakin lama akan semakin tunduk pada apa yang oleh C. Wright Mills (Johnson, 1991: 11) disebut sebagai 'keterpaksaan manajemen'. Pekerjaan profesi jurnalis di perusahaan pers telah terbagi dan terstandardisasi serta disesuaikan dengan bentuk kehirarkian perusahaan menurut keahlian pendidikan dan kemampuan memberi pelayanan. Tuntutan spesialisasi yang semakin sempit telah menggantikan syarat-syarat seperti kemampuan mengembangkan diri dan pengetahuan yang luas. Mereka menjalankan tugas-tugas yang bersifat rutin, dan yang sukses makin lama makin mendekati tipe manajer.

Di bawah patronase korporasi, para jurnalis di Batu TV harus bekerja sesuai dengan target yang ditentukan oleh manajemen, yaitu:

a. Mereka harus menulis berita dengan format 'berita langsung' (straight news), hanya dengan format straight news saja, secara rutin, setiap hari, dengan target kuantitatif. Dengan ini hendak dikatakan bahwa rutinitas menulis berita dengan target kuantitatif, membuat para jurnalis tidak dapat berkembang menjadi profesional. Sehingga tidak sempat menggunakan infrastruktur jurnalisme lain yang lebih canggih- in-depht reporting dan investigative reporting. Target BT di Batu TV menjadikan para jurnalis menjadi tidak kreatif. Bahkan dalam praktiknya, tidak jarang memuat berita tanpa melakukan wawancara, mengambil berita dari rekan wartawan lainnya dan menulis berita sesuai pesanan orang yang membayar.

b. Menulis berita dengan target kuantitatif membuat para jurnalis tidak pernah dapat dan sempat mengembangkan diri dengan "penyegaran", dengan menambah wawasan melalui pendidikan dan pelatihan, kerjasama dengan beberapa lembaga non-pemerintah, juga pemerintah. Bagi jurnalis di daerah yang perusahaan persnya belum mapan (oportunity cost) mengenai perhitungan keuntungan antara memilih tetap mengejar berita dengan imbalan honorarium, dan mengikuti penyegaran dengan imbalan sekadar wawasan.

c. Tidak adanya peningkatan profesionalitas jurnalis, barangkali juga disebabkan oleh keterpaksaan manajemen, yakni adanya rasio yang tidak seimbang antara jumlah pekerja profesi dengan beban pekerjaan. Jumlah pekerja profesi yang memiliki kompetensi kurang memadai untuk memikul beban pekerjaan yang terlalu besar. Meskipun dengan kondisi seperti ini, tetapi manajemen tetap memaksakannya. Jurnalis tetap menjadi mesin birokrasi korporasi. Pengawasan pekerjaan sepenuhnya dilakukan oleh perusahaan.

\section{PENUTUP}

\section{Simpulan}

1. Analisis hasil penelitian ini menunjukkan bahwa faktor keterampilan teknis dan kepatuhan etis jurnalis hanya berperan sebagai prakondisi menuju profesionalisme wartawan televisi, sebab ada tiga komponen penting lainnya yaitu 
otoritas, pengawasan, dan pelayanan. Dari aspek keterampilan teknis, hampir semua jurnalis Batu TV belajar jurnalisme secara otodidak, tidak didukung dengan pendidikan dan pelatihan secara formal. Hal ini mempengaruhi kualitas pemberitaan Batu TV, yaitu : 1)Analisis Berita ; Cara - cara penyiaran berita, Pengaturan tayangan berita, Analisis kebenaran berita; 2) Menulis pendapat dan komentar : penelusuran dari pelaku, penggalian pendapat dan komentar dari para ahli.

2. Pada kenyataannya, media massa telah dikontrol oleh korporasi dan karena itu mengaburkan makna kebebasan pers. Hubungan pekerja media dan pemilik modal tidak lagi sekedar sebagai relasi fungsional, akan tetapi sudah memperlihatkan dominasi yang menjadi model di berbagai institusi media. Tuntutan kapitalisme korporasi mengalahkan etika jurnalistik di Batu TV. Hal ini merupakan imbas tiadanya pengawasan, regulasi dan proses manajemen yang ketat. Jurnalis di Batu TV tidak menjadi pribadi "bebas" yang memproduksi kebenaran melalui hasil jurnalistik, namun lebih karena tuntutan kapitalisme korporasi. Hal ini dibuktikan dengan banyaknya berita pesanan, yang disebut blockingtime. Sehingga dalam peliputan sebuah berita, para jurnalis sering merasa bingung antara sebuah pemberitaan murni dengan berita pesanan.

3. Patronase korporasi melahirkan orangorang yang "dipelihara", apakah secara langsung sebagai pekerja atau dalam konteks kendali organisasi birokrasi profesional. Dalam hal jurnalis kita, mereka kebanyakan sebagai pekerja langsung perusahaan, sedangkan ikatannya dengan organisasi profesi amat longgar. Profesionalisme jurnalis di Batu TV tidak berkembang sebagaimana layaknya. Konsep lembaga penyiaran yang profesional tidak terlihat secara nyata diterapkan, sehingga harapan agar lembaga penyiaran berjalan sesuai standar etika jurnalistik yang menjunjung profesionalisme tidak kunjung terjadi. Batu TV hanya mememiliki empat wartawan dengan beban pekerjaan rangkap.

4. Kurangnya pengawasan terhadap keterampilan teknis berakibat pula pada kepatuhan etis wartawan. Yang semula wartawan harus mematuhi peraturan yang telah dibuat berupa Undang Undang Pers maupun Kode Etik Jurnalistik Televisi, wartawan sendiri harus lebih tunduk dengan aturan yang dibuat di Batu TV yang secara jelas tidak tertulis.

\section{Saran}

1. Seharusnya para wartawan lebih tunduk kepada aturan yang tertulis dan telah disepakati oleh beberapa lembaga profesi yang telah dilegalkan, bukan malah tunduk pada patronase korporasi media tersebut. Pada kondisi ini, profesionalisme jurnalis sudah tidak dapat dinilai karena wartawan tersebut tunduk pada aturan perusahaan dan intervensi pemilik Batu TV.

2. Aspek komersial dapat mengalahkan aspek publik. Wartawan harus senantiasa menyadari bahwa sajiannya berpengaruh besar terhadap perubahan perilaku, pola pikir, dan wawasan masyarakat. Sebuah sajian akan menumbuhkan empaty. Tugas media massa juga mendidik masyarakat, sehingga tidak adil jika filter untuk mencermati makna sebuah sajian diserahkan sepenuhnya kepada 
masyarakat tanpa ada seleksi yang bertangggung jawab dari para pekerja pers atas sajiannya. Pers hakikatnya bukan sekedar penjual berita dengan sajian menu berdasarkan selera pasar dan mempersilahkan pasar untuk memberikan penilaian akhir dan berikutnya menentukan pilihannya.

\section{DAFTAR PUSTAKA}

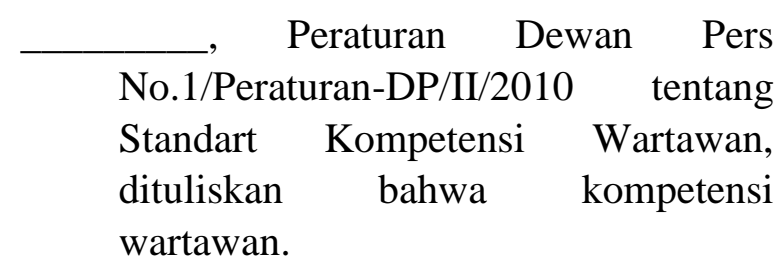

Abrar, Ana Nadhya. 2005. Penulisan Berita

Edisi Kedua. Yogyakarta: Universitas Atma Jaya Yogyakarta.

Anderson, R.H. 1987. Pemilihan dan Pengembangan Media untuk Pembelajaran. Jakarta: Rajawali.

Johnson, Terence J. , 1991, Profesi dan Kekuasaan. Jakarta: PT. Pustaka Utama Grafiti.
Kovach, Bill \& Tom Rosentiel. 2001. Sembilan Elemen Jurnalisme. Jakarta: Yayasan Pantau.

Kusumaningrat, Hikmat. 2005. Jurnalistik : Teori Dan Praktik. Bandung : Remaja Rosdakarya.

Moleong Lexi J, 2005, Metode Penelitian Kualitatif, Ed. Revisi, Bandung: PT.Remaja Rosdakarya.

Oetama, Jakoeb, 1985, Reportase Komprehensif. Jakarta : Pantja Simpati.

Shoemaker, Pamela J dan Stephen D. Reese. 1996. Mediating The Message. NewYork : Longman Publisher.

Siregar \& Suarjana, I Made (eds). 1995. Bagaimana Mempertimbangkan Artikel Opini Untuk MediaMassa. Jakarta : Penerbit Kanisius. Wahidin, Samsul. 1999. Tanggung Jawab Atas Pemberitaan Pers dalam Media Cetak. Disertasi. Surabaya: Program Pascasarjana UNAIR. 